\title{
Ethanolic extract of Brazilian green propolis sensitizes prostate cancer cells to TRAIL-induced apoptosis
}

\author{
EWELINA SZLISZKA ${ }^{1}$, GRZEGORZ ZYDOWICZ ${ }^{1}$, BEATA JANOSZKA ${ }^{2}$, \\ CEZARY DOBOSZ ${ }^{2}$, GRAZYNA KOWALCZYK-ZIOMEK ${ }^{3}$ and WOJCIECH KROL ${ }^{1}$ \\ Departments of ${ }^{1}$ Microbiology and Immunology, ${ }^{2}$ Chemistry and ${ }^{3}$ Histology and \\ Embryology, Medical University of Silesia in Katowice, \\ Jordana 19, 41808 Zabrze, Poland
}

Received September 24, 2010; Accepted December 3, 2010

DOI: 10.3892/ijo.2011.930

\begin{abstract}
Prostate cancer represents an ideal disease for chemopreventive intervention. Propolis possesses immunomodulatory, anti-tumour and chemopreventive properties. The tumour necrosis factor-related apoptosis-inducing ligand (TRAIL) is an important endogenous anti-cancer agent that induces apoptosis selectively in tumour cells. However, some cancer cells are resistant to TRAIL-mediated apoptosis. Naturally occurring phenolic and polyphenolic compounds sensitize TRAIL-resistant cancer cells and augment the apoptotic activity of TRAIL. The ethanolic extract of Brazilian green propolis (EEP) is rich in phenolic components. Our in vitro results indicate the potential targets in the TRAILinduced apoptotic pathway for the cancer chemopreventive activity of Brazilian propolis. We examined the cytotoxic and apoptotic effects of Brazilian EEP and its bioactive components in combination with TRAIL on LNCaP prostate cancer cells. The chemical composition of Brazilian green propolis was determined by high performance liquid chromatographydiode array detection. The cytotoxicity was measured by 3-[4,5-dimethylthiazol-2-yl]-2,5 diphenyl-tetrazolium and lactate dehydrogenase assays. Apoptosis was detected using annexin V-FITC by flow cytometry and fluorescence microscopy. The mitochondrial membrane potential $(\Delta \Psi \mathrm{m})$ was evaluated using DePsipher staining by fluorescence microscopy. Flow cytometry was used to analyse death receptor (TRAIL-R1 and TRAIL-R2) expression in LNCaP cells. The inhibition of nuclear factor- $\kappa \mathrm{B}(\mathrm{NF}-\kappa \mathrm{B})(\mathrm{p} 65)$ activation in cancer cells was confirmed by the ELISA-based TransAM $\mathrm{NF}-\kappa \mathrm{B}$ kit. The LNCaP cells were shown to be resistant to
\end{abstract}

Correspondence to: Professor Wojciech Krol, Department of Microbiology and Immunology, Medical University of Silesia in Katowice, Jordana 19, 41808 Zabrze, Poland

E-mail: wkrol@sum.edu.pl

Key words: Brazilian green propolis, TRAIL, prostate cancer, apoptosis, chemoprevention
TRAIL-induced apoptosis. Our study demonstrates that EEP sensitizes TRAIL-resistant prostate cancer cells. The main phenolic components detected in Brazilian green propolis are artepillin $\mathrm{C}$, quercetin, kaempferol and $p$-coumaric acid. Brazilian propolis and its bioactive components markedly augmented TRAIL-mediated apoptosis and cytotoxicity in prostate cancer cells. Brazilian EEP enhanced the expression of TRAIL-R2 and the activity of NF- $\kappa \mathrm{B}$ in LNCaP cells. The co-treatment of prostate cancer cells with $100 \mathrm{ng} / \mathrm{ml}$ TRAIL and $50 \mu \mathrm{g} / \mathrm{ml}$ EEP increased the percentage of apoptotic cells to $65.8 \pm 1.2 \%$ and caused a significant disruption of $\Delta \Psi \mathrm{m}$ in LNCaP cells. We show that Brazilian EEP helped cells overcome TRAIL resistance by engaging both intrinsic and extrinsic apoptotic pathways and regulating $\mathrm{NF}-\kappa \mathrm{B}$ activity. The data demonstrate the important role of Brazilian green propolis and its bioactive compounds in prostate cancer chemoprevention through the enhancement of TRAILmediated apoptosis.

\section{Introduction}

Prostate cancer is one of the most commonly diagnosed cancers in men and is the second leading cause of cancerrelated deaths in the European Union and the United States of America $(1,2)$. The use of naturally occurring or synthetic agents is becoming increasingly recognized as an effective strategy in prostate cancer prevention (3). Prostate cancer represents an ideal disease for chemopreventive intervention because of its long latency, late age of onset, relatively slow rate of growth and progression, high incidence, tumour marker availability, identifiable pre-neoplastic lesions and risk groups $(3,4)$. The role of natural food products in the prevention of prostate cancer has been confirmed in numerous laboratory and epidemiology findings. Because of these observations, nutritional supplements, such as soybean, green tea, turmeric, vegetables and fruits or plant extract rich in polyphenolic compounds, play a significant role in prostate cancer chemoprevention $(3,5)$. In vitro and in vivo studies have shown the ability of polyphenols to enhance the apoptotic activity of the tumour necrosis factor-related apoptosis-inducing ligand (TRAIL) against prostate cancer cells (6-14). 
TRAIL, a member of the TNF superfamily, selectively induces apoptosis in cancer cells with no toxicity against normal tissues. TRAIL molecules are expressed on the cell surface of T lymphocytes, natural killer cells, dendritic cells, neutrophils and monocytes or macrophages, and can be cleaved into a soluble secreted form. TRAIL plays an important role in immune surveillance and defence mechanisms against tumour cells (15-17). Endogenous TRAIL triggers apoptotic signalling via receptor-mediated death through its interaction with the death receptors (DRs) on the surface of cancer cells $(16,18)$. TRAIL initiates programmed cell death upon binding to TRAIL-R1 (DR4) and/or TRAIL-R2 (DR5) receptors, and promotes the recruitment of the adaptor molecule Fas-associated death domain (FADD) with the formation of the death inducing signalling complex (DISC) and the activation of caspase- 8 and subsequent effector caspases. Apoptosis can also be mediated by the intrinsic pathway, with the implication of mitochondrial dysfunction. The link between the extrinsic and intrinsic signalling pathways is formed by the Bid (BH3-interacting domain death agonist) protein, which is cleaved and activated by caspase- 8 . However, some tumour cells are resistant to TRAIL-induced cytotoxicity. Failure to undergo apoptosis has been implicated in the resistance of cancer cells to TRAIL surveillance and therefore in tumour development. The expression of the DRs, TRAIL-R1 or TRAIL-R2, and pro-apoptotic or anti-apoptotic proteins in cancer cells is involved in TRAIL-resistance (17-19). We and others have shown that TRAIL-resistant prostate cancer cells can be sensitized by bioactive polyphenols (7-14).

One of the richest sources of polyphenols is propolis, a resinous product collected by honeybees from various plants and used widely in folk medicine for its therapeutic benefits. Propolis cannot be used as a raw material, so it must be purified by extraction to remove the inert material and preserve the polyphenolic fraction (20). The ethanolic extract of propolis (EEP) has attracted the interest of researchers in the last decade because of its many biological properties, such as antioxidant, immunomodulatory, chemopreventive and anticancer effects (11,20-29). These data suggest that propolis regulates multiple signalling pathways and has the potential to improve health and prevent diseases. EEP contains a variety of different chemical compounds, including phenolic acids or their esters, flavonoids (flavones, flavanones, flavonols, dihydroflavonols, chalcones), terpenes, aromatic aldehydes and alcohols, fatty acids, stilbenes and $\beta$-steroids $(20,27)$. Phenolic compounds isolated from propolis have been reported to induce the activities of the immune system and to exert antitumour and chemopreventive effects (30).

We previously reported the efficacy of European propolis in increasing the apoptotic activity of TRAIL in HeLa cervical, DU145 and LNCaP prostate cancer cells $(11,28)$. We then tested the apoptotic and cytotoxic effects of Brazilian EEP in combination with TRAIL on LNCaP prostate cancer cells and investigated the molecular mechanisms by which propolis helps LNCaP cells overcome TRAIL resistance. Our studies showed for the first time that Brazilian EEP markedly augments TRAIL-mediated apoptosis in prostate cancer cells and sensitizes LNCaP cells to TRAIL-induced programmed death. We analyzed the composition of the Brazilian green propolis sample and confirmed the role of its main phenolic components (artepillin C, quercetin, kaempferol and $p$-coumaric acid) in the enhancement of TRAIL-mediated apoptosis in $\mathrm{LNCaP}$ prostate cancer cells.

\section{Materials and methods}

Chemicals and reagents. The Brazilian green propolis sample was kindly supplied by Nihon Natural Foods Co., Ltd. (Tokyo, Japan). Quercetin, kaempferol and $p$-coumaric acid were obtained from Alexis Biochemicals (San Diego, CA, USA) and 3,5-diprenyl-4-hydroxycinnamic acid (artepillin C) was obtained from Wako Pure Chemicals (Osaka, Japan). The tested compounds were dissolved in dimethylsulfoxide (DMSO) to obtain the working concentrations. Soluble recombinant human TRAIL (rhsTRAIL) was purchased from PeproTech Inc. (Rocky Hill, NJ, USA).

Preparation of green propolis extact. The Brazilian green propolis sample was collected manually from beehives located in southeast Brazil (the state of Minas Gerais), and was kept desiccated prior to processing. The sample was extracted in 95\% v/v ethyl alcohol, in a hermetically-sealed glass vessel for 4 days at $37^{\circ} \mathrm{C}$, under occasional shaking. The Brazilian EEP was then filtered through Whatman filter paper no. 4 and evaporated in a rotary evaporator, under reduced pressure at $60^{\circ} \mathrm{C}$. The same collection and extraction procedures were used throughout all our laboratory studies $(11,20,28)$. EEP was dissolved in DMSO $(50 \mathrm{mg} / \mathrm{ml})$, and the final concentration of DMSO in the culture medium was controlled at $0.1 \%(\mathrm{v} / \mathrm{v})$.

Determination of the Brazilian green propolis profile by the high performance liquid chromatography-diode array detection (HPLC-DAD) method. The main constituents of the ethanolic extract of Brazilian green propolis were analyzed by HPLC-DAD. Standard mixtures in ethanol (concentrations, 0.01 and $0.02 \mathrm{mg} / \mathrm{ml}$ ) containing $p$-coumaric acid, quercetin, kaempferol and artepillin C (3,5-diprenyl-4-hydroxycinnamic acid) were prepared from standard stock solutions (each at a concentration of $0.1 \mathrm{mg} / \mathrm{ml}$ in ethanol). Brazilian green propolis extracts at concentrations of 43.5 and $2.175 \mathrm{mg} / \mathrm{ml}$ in ethanol were used for the HPLC analysis. A HPLC-DAD Ultimate 3000 Dionex system (Germering, Germany) with an autosampler was used. Separation was performed on a Luna C18 column ( $5 \mathrm{~mm}$ particle size, $250 \times 3 \mathrm{~mm}$ ID) from Phenomenex and a mobile phase consisting of $0.1 \%$ formic acid in water (solvent A) and $0.08 \%$ formic acid in acetonitrile (solvent B). The separations were performed with a gradient elution: $20-30 \%$ solvent B (for $15 \mathrm{~min}$ ), $30 \%$ solvent B (15-28 min), 30-80\% solvent B (28-50 min), $80 \%$ solvent B (50-54 min), 80-40\% solvent B (54-60 min) and 40-20\% solvent B (60-65 min). Such a mobile phase and a similar gradient program have been previously used by Kumazawa et al for the analysis of the antioxidant propolis constituents (26). The flow-rate was $0.8 \mathrm{ml} / \mathrm{min}$. All separations were carried out at $30^{\circ} \mathrm{C}$. The injection volume ranged from 2-30 $\mu 1$. UV detection was conducted at 290, 308, 325 and $370 \mathrm{~nm}$. Qualitative analysis was based on the comparison of retention times and UV spectra recorded for standards with the values of appropriate components identified in the Brazilian propolis 
extract sample run under the same conditions. The concentrations of individual compounds were determined by using an external calibration curve method from the plots constructed in the range from 40-300 ng/column at $308 \mathrm{~nm}$ (for $p$-coumaric acid and artepillin C) and $370 \mathrm{~nm}$ (for quercetin and kaempferol). Correlation coefficients $\left(\mathrm{R}^{2}\right)$ for the curves recorded were from 0.9931 (kaempferol) to 0.9998 ( $p$-coumaric acid and artepillin $\mathrm{C}$ ).

Cell line and culture. The human hormone-sensitive prostate cancer LNCaP cell line was obtained from the German Collection of Microorganisms and Cell Cultures (DSMZ, Braunschweig, Germany). LNCaP cells were maintained in RPMI-1640 medium with 10\% fetal bovine serum, $4 \mathrm{mM}$ L-glutamine, $100 \mathrm{U} / \mathrm{ml}$ penicillin and $100 \mu \mathrm{g} / \mathrm{ml}$ streptomycin and were grown in monolayer cultures at $37^{\circ} \mathrm{C}$ and $5 \% \mathrm{CO}_{2}$ $(11,13,31)$. Reagents for cell culture were purchased from PAA, The Cell Culture Company (Pasching, Austria).

Cytotoxicity assay. Cytotoxicity was measured by the 3-[4,5dimethylthiazol-2-yl]-2,5 diphenyl-tetrazolium (MTT) assay as previously described $(31,32)$. The MTT assay is based on the cleavage of the tetrazolium salt MTT to the blue formazan dye by viable cells. The LNCaP cells $\left(2 \times 10^{5} / \mathrm{ml}\right)$ were seeded in a 96 -well plate $48 \mathrm{~h}$ prior to the experiments. Various combinations of EEP $(20-50 \mu \mathrm{g} / \mathrm{ml})$ or its components (20-50 $\mu \mathrm{M})$ with or without TRAIL (50-200 $\mathrm{ng} / \mathrm{ml})$ were added to the cells. After $48 \mathrm{~h}$ the medium was removed, and $20 \mu \mathrm{l}$ of MTT solution $(5 \mathrm{mg} / \mathrm{ml}$ ) (Sigma Chemical Company, St. Louis, MO, USA) were added to each well for $4 \mathrm{~h}$. The resulting crystals were dissolved in DMSO. The controls included native cells and medium only. The spectrophotometric absorbance at $550 \mathrm{~nm}$ was measured using a microplate reader (ELx 800, Bio-Tek Instruments Inc., Winooski, VT, USA). The percentage cytotoxicity was calculated by the formula: Percentage cytotoxicity (cell death) $=[1-($ absorbance of experimental wells/absorbance of control wells)] x $100 \%$.

Lactate dehydrogenase release assay. Lactate dehydrogenase $(\mathrm{LDH})$ is a stable cytosolic enzyme that is released upon membrane damage in necrotic cells. LDH activity was measured using a commercial cytotoxicity assay kit (Roche Diagnostics GmbH, Mannheim, Germany), in which the LDH released in culture supernatants is measured with a coupled enzymatic assay, resulting in the conversion of a tetrazolium salt into a red formazan product. The LNCaP cells were treated with various concentrations of EEP $(20-50 \mu \mathrm{g} / \mathrm{ml})$ or its components $(50 \mu \mathrm{M})$ alone or in combination with TRAIL (50-200 $\mathrm{ng} / \mathrm{ml})$ for the indicated period of time. The sample solution (supernatant) was removed, and the LDH released from the cells into the culture medium was measured. The maximal release was obtained after treating the control cells with $1 \%$ Triton X-100 (Sigma Chemical Company) for $10 \mathrm{~min}$ at room temperature (31-33). The necrotic percentage was expressed using the formula: (Sample value/maximal release) $\mathrm{x} 100 \%$.

Detection of apoptosis by flow cytometry. Apoptosis was measured using flow cytometry to quantify the levels of phosphatidylserine (PS) on the outer membrane of apoptotic cells.
Externalized PS on the outer surface of the cytoplasmic membrane becomes labelled by annexin V-FITC, which has a high affinity for PS-containing phospholipid bilayers. The annexin $\mathrm{V}$ assay was performed using the Apoptotest-FITC Kit (Dako, Glostrup, Denmark). The LNCaP cells $\left(2 \times 10^{5} / \mathrm{ml}\right)$ were seeded in 24-well plates for $48 \mathrm{~h}$ and then exposed to EEP $(20-50 \mu \mathrm{g} / \mathrm{ml})$ or its components $(50 \mu \mathrm{M})$ and/or TRAIL (50-200 ng/ml) for $48 \mathrm{~h}$. After this time, the cancer cells were washed twice with phosphate-buffered saline (PBS) solution and resuspended in $1 \mathrm{ml}$ of binding buffer. The cell suspension (500 $\mu \mathrm{l}$ ) was then incubated with $5 \mu \mathrm{l}$ of annexin V-FITC and $10 \mu \mathrm{l}$ of propidium iodide (PI) for $10 \mathrm{~min}$ at room temperature in the dark. The population of annexin V-positive cells was evaluated by flow cytometry (BD FACScan, Becton-Dickinson Immnunocytometry Systems, San Jose, CA, USA) (11,13,25, 31,32).

Detection of apoptosis by fluorescence microscopy. Apoptotic cells were quantified by the fluorescence microscopy method using the Apoptotic, Necrotic and Healthy Cells Quantification Kit from Biotium, Inc. (Hayward, CA, USA) according to the instructions of the manufacturer (32-34). The LNCaP cells $\left(2.5 \times 10^{5} / \mathrm{ml}\right)$ were seeded in a 24 -well plate $24 \mathrm{~h}$ prior to the experiments. EEP $(50 \mu \mathrm{g} / \mathrm{ml})$ with or without TRAIL (100 ng/ $\mathrm{ml}$ ) was added to the cancer cells, and $48 \mathrm{~h}$ later, the cells were washed with PBS and detached from the cell culture wells by trypsin. The LNCaP cells were then centrifuged to discard the supernatant, washed with PBS and resuspended in binding buffer $(100 \mu \mathrm{l} / \mathrm{sample})$. A combination of $5 \mu \mathrm{l}$ of annexin V- FITC, $5 \mu \mathrm{l}$ of ethidium homodimer III and $5 \mu \mathrm{l}$ of Hoechst 33342 solutions was added to each tube. The samples were incubated at room temperature for $15 \mathrm{~min}$ in the dark. After staining, the cancer cells were washed with binding buffer, placed on a glass slide and covered with a glass cover slip. The stained cells were observed under a fluorescence inverted microscope IX51 (Olympus, Tokyo, Japan) using filter sets for FITC, TRITC and DAPI. The healthy cells (stained with Hoechst 33342) emitted blue fluorescence, apoptotic cells (stained with annexin V-FITC and Hoechst 33342) emitted green and blue fluorescence, and necrotic cells (stained with ethidium homodimer III and Hoechst 33342) emitted red and blue fluorescence. Cancer cells stained with blue, red and green, were dead cells progressing from the apoptotic cell population. The cells were counted, and the apoptotic cells were expressed as a percentage of the total cells.

Evaluation of mitochondrial potential by DePsipher. The DePsipher Kit (R\&D Systems, Minneapolis, MN, USA) was used to measure the mitochondrial membrane potential $(\Delta \Psi \mathrm{m})$ in the fluorescence microscopy assay according to the manufacturer's instructions (34). The LNCaP cells $\left(2.5 \times 10^{5} / \mathrm{ml}\right)$ were seeded in a 24 -well plate $24 \mathrm{~h}$ prior to the experiments. The EEP $(50 \mu \mathrm{g} / \mathrm{ml})$ with or without TRAIL $(100 \mathrm{ng} / \mathrm{ml})$ was added to the cancer cells, and $48 \mathrm{~h}$ later the cells were washed with PBS and detached from the cell culture wells by trypsin. The cells were incubated in the dark with DePsipher $(5,5,6,6$ 'tetrachloro-1,1',3,3'tetraethyl-benzimidazolyl carbocyanin iodide) solution at a concentration of $5 \mu \mathrm{g} / \mathrm{ml}$ for $30 \mathrm{~min}$ at $37^{\circ} \mathrm{C}$, washed with reaction buffer with stabilizer, placed on a glass slide and covered with a glass cover slip. The stained 
cells were observed under a fluorescence inverted microscope IX51 (Olympus) using filter sets for FITC and TRITC. DePsipher exhibits potential-dependent accumulation in mitochondria, indicated by a fluorescence emission shift from red $(590 \mathrm{~nm})$ to green $(530 \mathrm{~nm})$. In healthy cells, the mitochondria contain red spots following the aggregation of the DePsipher within the mitochondria. In cells with a disrupted potential, the dye remains in its monomeric form in the cytoplasm, and uniform green fluorescence appears.

Flow cytometric analysis of DR expression on the cell surface. The cell surface expression of the DRs, TRAIL-R1 and TRAIL-R2, on prostate cancer cells was measured by flow cytometry (BD FACSCanto, Becton-Dickinson Immnunocytometry Systems). LNCaP cells $\left(2.5 \times 10^{5 /} \mathrm{ml}\right)$ were seeded in 24-well plates for $24 \mathrm{~h}$ and then exposed to EEP $(50 \mu \mathrm{g} / \mathrm{ml})$ for $48 \mathrm{~h}$. The cells were then harvested using trypsin and ethylenediaminetetraacetic acid, washed twice in PBS and resuspended in PBS containing $0.5 \%$ bovine serum albumin. The cells were incubated with $10 \mu 1$ phycoerythrin-conjugated anti-TRAIL-R1 or anti-TRAIL-R2 monoclonal antibodies (R\&D Systems) at $4^{\circ} \mathrm{C}$ for $45 \mathrm{~min}$. After staining, the cancer cells were washed with PBS and finally analyzed by flow cytometry (7,35-37). The control consisted of cells in a separate tube treated with phycoerythrin-labeled mouse $\mathrm{IgG}_{1}$ or mouse $\mathrm{IgG}_{2 \mathrm{~B}}$ antibodies ( $\mathrm{R} \& \mathrm{D}$ Systems).

Nuclear factor $-\kappa B(N F-\kappa B)$ activity. The NF- $\mathrm{B}$ (p65) binding activity in the nuclear extract was measured using the ELISAbased TransAm NF- $\mathrm{BB}$ kit (Active Motif Europe, Rixensart, Belgium). The LNCaP cells $\left(1 \times 10^{6} / \mathrm{ml}\right)$ were seeded in petri dishes $24 \mathrm{~h}$ prior to the experiments. EEP $(50 \mu \mathrm{g} / \mathrm{ml})$ with or without TRAIL (100 ng/ml) was added to the cancer cells, and $48 \mathrm{~h}$ later, the cells were washed with PBS and detached from the cell culture wells by trypsin. The commercially available Nuclear Extract kit was obtained from Active Motif Europe (Rixensart) for preparation of LNCaP cell nuclear extracts. The TransAM NF- $\kappa$ B assay for NF- $\kappa$ B (p65) activity was performed according to the manufacturer's instructions (38). NF-кB DNA-binding activity was assessed by using the transcription factor $\mathrm{p} 65$ ELISA kit. Oligonucleotides containing the NF- $\kappa \mathrm{B}$ consensus site (5'-GGGACTTCC-3') were immobilized on a 96 -well plate. The active forms of $N F-\kappa B$ in the nuclear extracts were bound to the oligonucleotides on the plate and detected colorimetrically by spectrophotometry at an absorbance of $450 \mathrm{~nm}$ with a reference wavelength of $650 \mathrm{~nm}$. The detection limit for the TransAm NF- $\kappa$ B kit is $<0.4 \mathrm{ng} / \mathrm{ml}$ purified $\mathrm{p} 65$.

Statistical analysis. The results are expressed as the means \pm SD obtained from three independent experiments performed in quadruplicate $(n=12)$ or duplicate $(n=6)$. Statistical significance was evaluated using the Levene or Bartlett Chi-square test followed by analysis of variance (ANOVA). A p-value of $<0.05$ was considered to be significant.

\section{Results}

Cytotoxic and apoptotic effects of TRAIL on prostate cancer cells. TRAIL induced cytotoxic and apoptotic effects in LNCaP prostate cancer cells in a dose-dependent manner. The cytotoxicity of TRAIL at concentrations of 50-200 ng/ml after a 48-h incubation was between $13.76 \pm 0.66$ and $23.84 \pm 0.60 \%$. TRAIL-induced apoptosis in LNCaP cells was determined by annexin V staining. The 48-h exposure to TRAIL increased the percentage of apoptotic cells from $15.37 \pm 0.38$ to $25.71 \pm 0.36 \%$. The results show that TRAIL is less active against the tested prostate cancer cell line and confirm the resistance of $\mathrm{LNCaP}$ cells to TRAIL-mediated apoptosis and cytotoxicity.

Cytotoxic and apoptotic effects of Brazilian green propolis on prostate cancer cells. The prostate cancer cells were incubated for $48 \mathrm{~h}$ with EEP at concentrations of $20-50 \mu \mathrm{g} / \mathrm{ml}$. We demonstrate that treatment of LNCaP cells with Brazilian green propolis inhibits cell proliferation by inducing cytotoxicity and apoptosis in a dose-dependent manner. The cytotoxic effect of EEP on LNCaP cells was between $3.38 \pm 0.84$ and $8.27 \pm 0.95 \%$. The annexin $\mathrm{V}$ assay revealed apoptotic cells exposed to EEP. Brazilian propolis induced $4.71 \pm 0.57$ to $10.64 \pm 0.73 \%$ apoptosis in prostate cancer cells. The EEP exhibited low cytotoxic and apoptotic activities against LNCaP cells.

Cytotoxic and apoptotic effects of TRAIL in combination with Brazilian green propolis on prostate cancer cells. We investigated the cytotoxic and apoptotic effects of TRAIL in combination with Brazilian green propolis on prostate cancer cells. The co-treatment of LNCaP cells with TRAIL at concentrations of $50-200 \mathrm{ng} / \mathrm{ml}$ and EEP at concentrations of $20-50 \mu \mathrm{M}$ increased the percentage of cell death to $35.77 \pm 0.78$ $65.93 \pm 1.27 \%$. The cytotoxicity measured by MTT assay is shown in Fig. 1A. We found that Brazilian green propolis strongly cooperated with TRAIL to induce apoptosis in prostate cancer cells. The percentage of the apoptotic cells stained with annexin V-FITC detected by flow cytometry after a 48-h exposure to $100 \mathrm{ng} / \mathrm{ml}$ TRAIL with $50 \mu \mathrm{g} / \mathrm{ml}$ EEP was elevated to $64.41 \pm 0.55 \%$ (Fig. 1B). The necrotic cell death percentage of LNCaP cells examined by Apoptest-FITC and the lactate dehydrogenase assay was near zero. The annexin V-FITC staining by fluorescence microscopy (Fig. 1C) confirmed the augmentation of the apoptotic activity of TRAIL by EEP against LNCaP cells. Brazilian propolis enhanced the apoptosis-inducing potential of TRAIL and sensitized TRAIL-resistant LNCaP prostate cancer cells.

Effect of Brazilian green propolis and TRAIL on $\Delta \Psi_{m}$ in prostate cancer cells. Disruption of $\Delta \Psi \mathrm{m}$ has been shown to be one of the first intracellular changes following the onset of apoptosis. Treatment of LNCaP cells with $50 \mu \mathrm{g} / \mathrm{ml}$ EEP and $100 \mathrm{ng} / \mathrm{ml}$ TRAIL alone caused little effect on $\Delta \Psi \mathrm{m}$ $(8.63 \pm 0.74 \%$ and $18.25 \pm 1.04 \%$, respectively). The combination of Brazilian propolis and TRAIL produced an enhanced loss of $\Delta \Psi \mathrm{m}(61 \pm 1.31 \%)$ and induced a significant disruption of $\Delta \Psi \mathrm{m}$ in LNCaP cells (Fig. 2A and B). These data suggest that the effect of EEP on TRAIL-induced apoptosis is mitochondriadependent.

Effect of Brazilian green propolis on DR expression in prostate cancer cells. We analyzed the expression of the TRAIL-R1 and TRAIL-R2 DRs on LNCaP cells after a 48-h treatment 


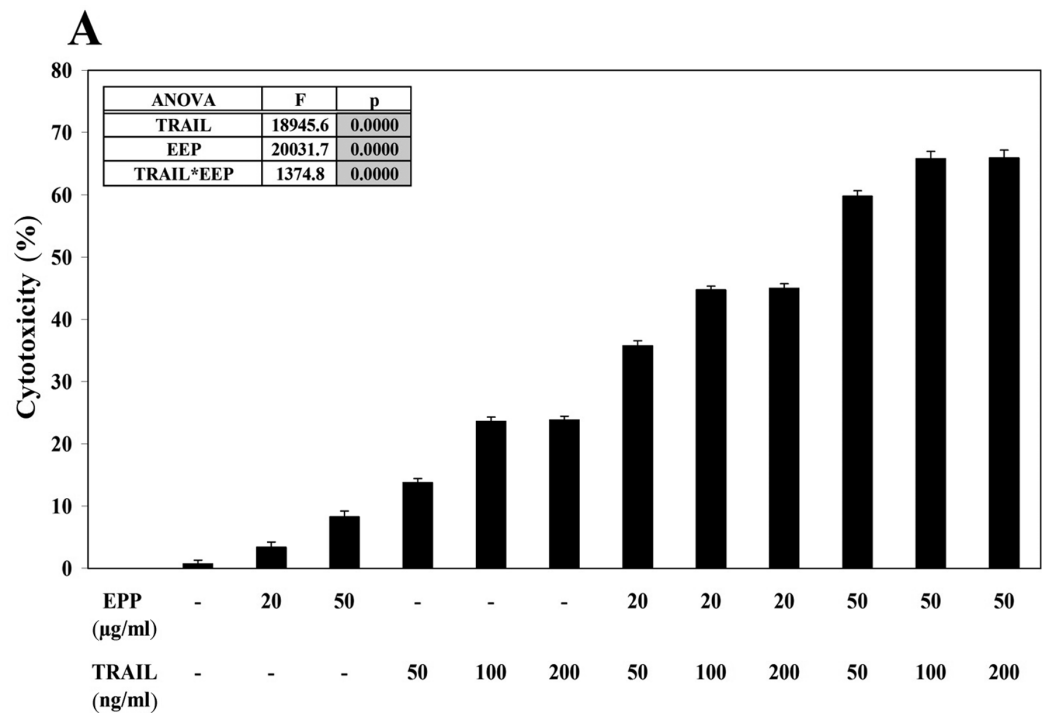

B

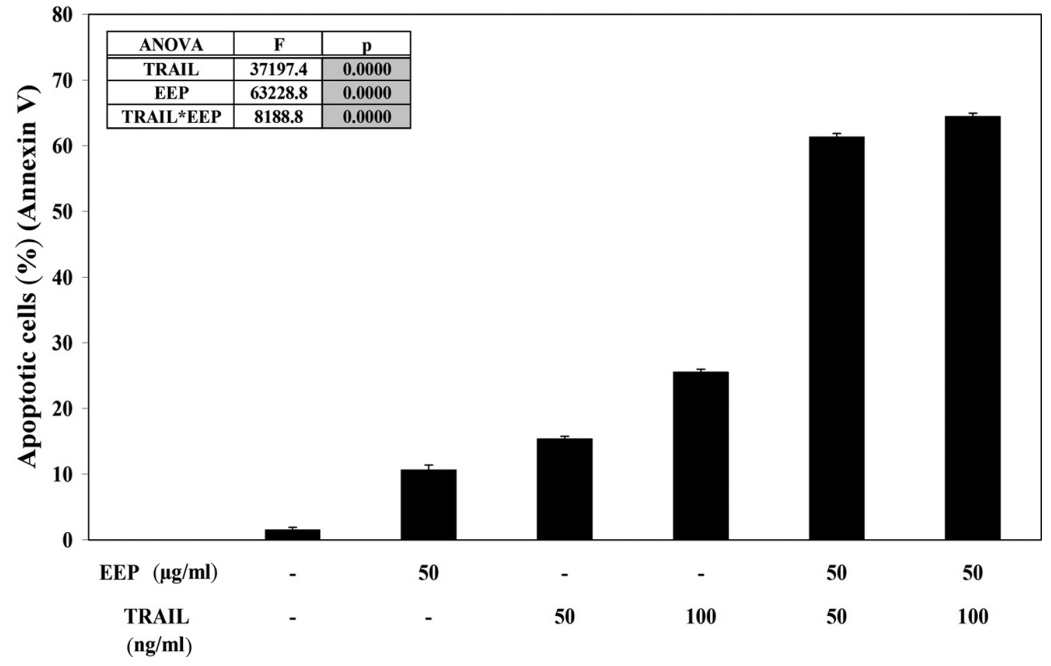

C
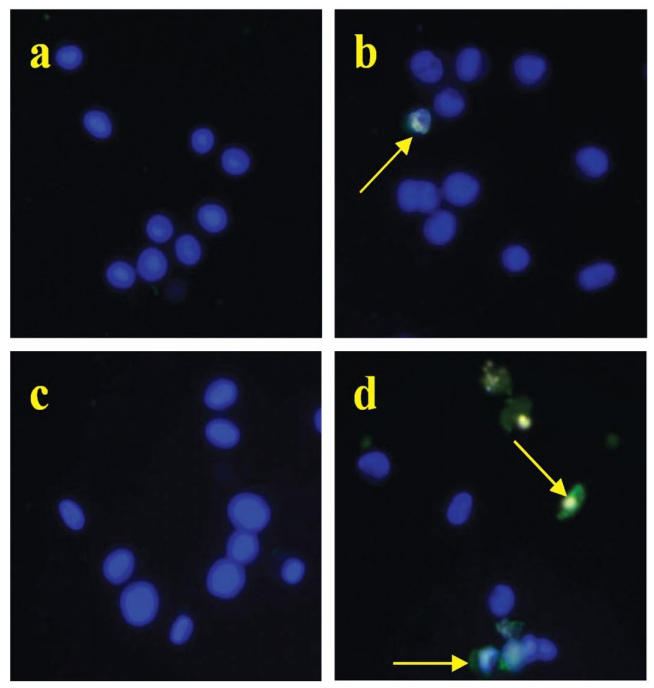

Figure 1. Cytotoxic and apoptotic effects of TRAIL in combination with Brazilian green propolis on LNCaP prostate cancer cells. (A) Cytotoxic activity of TRAIL in combination with Brazilian EEP in LNCaP cells. The cancer cells were incubated for $48 \mathrm{~h}$ with TRAIL at concentrations of $50-200 \mathrm{ng} / \mathrm{ml}$ and Brazilian EEP at concentrations of $20-50 \mu \mathrm{g} / \mathrm{ml}$. The values represent the means $\pm \mathrm{SD}$ of three independent experiments performed in quadruplicate $n=12(p<0.05)$. The percentage of cell death was measured by MTT cytotoxicity assay. (B) TRAIL-induced apoptosis in combination with Brazilian EEP in LNCaP prostate cancer cells. The cancer cells were incubated for $48 \mathrm{~h}$ with TRAIL at concentrations of $50-100 \mathrm{ng} / \mathrm{ml}$ and Brazilian EEP at a concentration of $50 \mu \mathrm{g} / \mathrm{ml}$. The values represent the means \pm SD of three independent experiments performed in duplicate $n=6(\mathrm{p}<0.05)$. Apoptotic cell death was detected by annexin V-FITC staining using flow cytometry. (C) TRAIL-induced apoptosis in combination with Brazilian EEP in LNCaP prostate cancer cells: a) Control cells, b) cells incubated with TRAIL (100 ng/ml), c) cells incubated with Brazilian EEP $(50 \mu \mathrm{g} / \mathrm{ml})$, and d) cells incubated with TRAIL $(100 \mathrm{ng} / \mathrm{ml})$ and Brazilian EEP $(50 \mu \mathrm{g} / \mathrm{ml})$. Apoptotic cell death was detected by annexin V-FITC staining using fluorescence microscopy. The healthy cells (stained with Hoechst 33342) emitted blue fluorescence, and apoptotic cells (stained with Hoechst 33342 and annexin V- FITC) emitted blue and green fluorescence (indicated by arrows).

with $50 \mu \mathrm{g} / \mathrm{ml}$ EEP by flow cytometry (Fig. 3A and B). Brazilian green propolis increased TRAIL-R2 expression levels in prostate cancer cells. However, TRAIL-R1 expression levels did not change.
Effect of Brazilian green propolis and TRAIL on NF- $\kappa B$ activity in prostate cancer cells. We tested (Fig. 4) the effect of Brazilian green propolis and/or TRAIL on NF- $\kappa$ B activation in prostate cancer cells. We detected the p65 subunit binding 


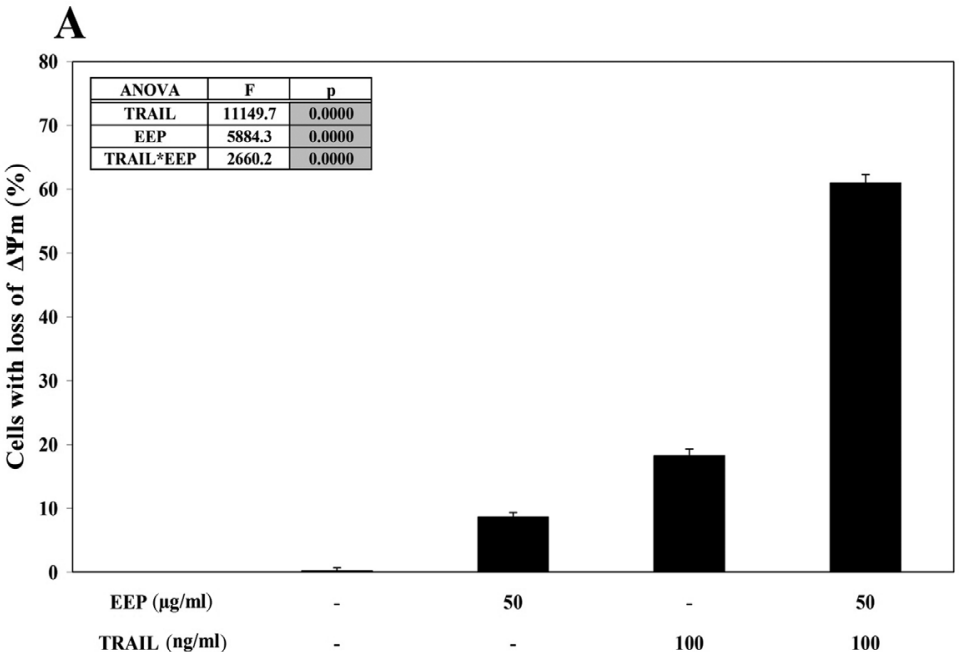

B
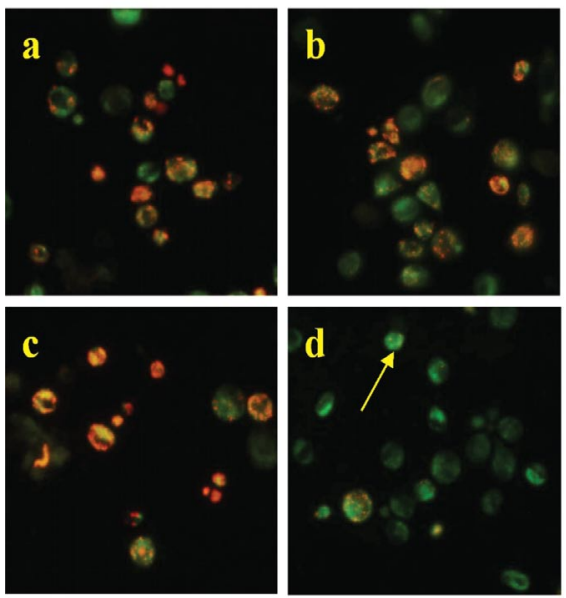

Figure 2. Effect of TRAIL in combination with Brazilian green propolis on the mitochondrial membrane potential $(\Delta \Psi \mathrm{m})$ in $\mathrm{LNCaP}$ prostate cancer cells. The cancer cells were incubated for $48 \mathrm{~h}$ with TRAIL at a concentration of $100 \mathrm{ng} / \mathrm{ml}$ and Brazilian EEP at a concentration of $50 \mu \mathrm{g} / \mathrm{ml}$. (A) TRAIL in combination with Brazilian EEP induced the loss of $\Delta \Psi \mathrm{m}$ in LNCaP cells. The values represent the means $\pm \mathrm{SD}$ of three independent experiments performed in duplicate $n=6(p<0.05)$. Red fluorescence is emitted from the red aggregates of the DePsipher, which are formed within the mitochondria in healthy cells. Green fluorescence reveals the monomeric form of the DePsipher molecule, which appears in the cytosol after mitochondrial membrane depolarization. (B) The loss of $\Delta \Psi \mathrm{m}$ in $\mathrm{LNCaP}$ cells was assessed by fluorescent microscopic analysis of DePsipher staining: a) Control cells, b) cells incubated with TRAIL (100 ng/ml), c) cells incubated with Brazilian EEP $(50 \mu \mathrm{g} / \mathrm{ml})$, and d) cells incubated with TRAIL $(100 \mathrm{ng} / \mathrm{ml})$ and Brazilian EEP $(50 \mu \mathrm{g} / \mathrm{ml})$. Cells with a high mitochondrial membrane potential form DePsipher aggregates that are detected by red fluorescence. In contrast, in cells with a low mitochondrial membrane potential, the DePsipher becomes a monomer displaying green fluorescence (indicated by arrows).

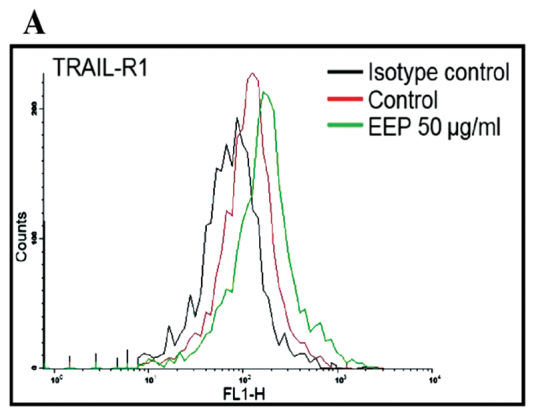

B

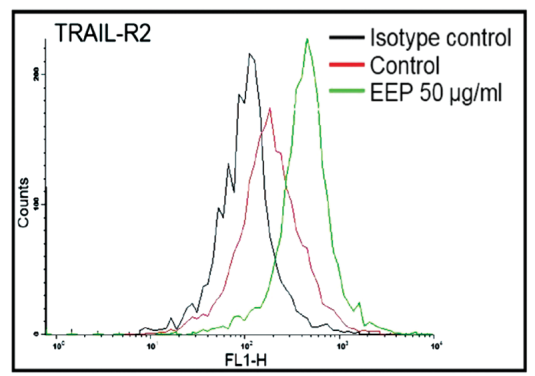

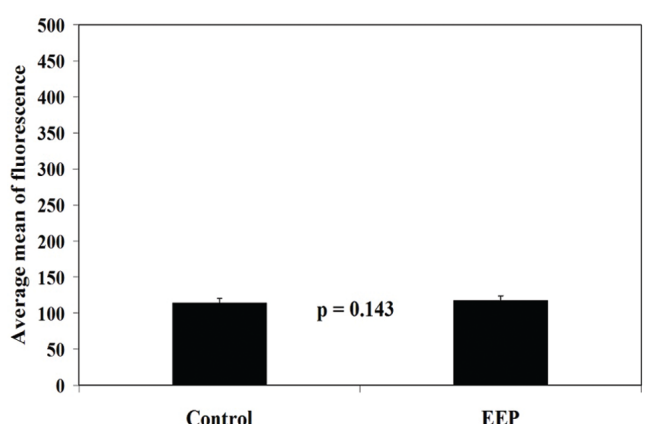

Control

EEP

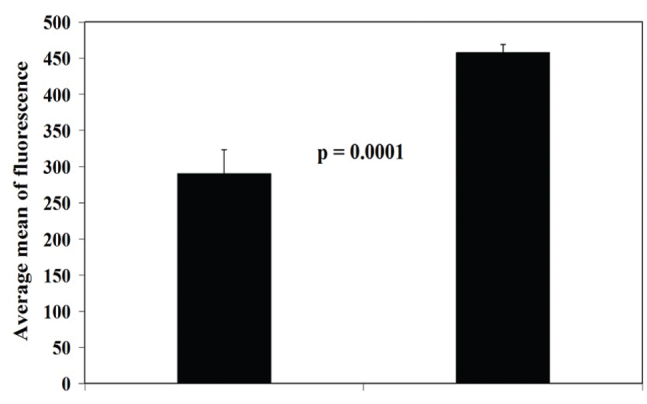

EEP

Figure 3. Effect of Brazilian green propolis on death receptor expression in LNCaP prostate cancer cells. The cancer cells were incubated for $48 \mathrm{~h}$ with Brazilian EEP at a concentration of $50 \mu \mathrm{g} / \mathrm{ml}$. The expression of the death receptors, TRAIL-R1 and TRAIL-R2, in LNCaP cells was measured by flow cytometric analysis. Representative histograms and the average mean fluorescence from three independent experiments performed in duplicate $n=6$ is presented (A) for TRAIL-R1 expression and (B) for TRAIL-R2 expression in cancer cells. The values represent the means \pm SD $(\mathrm{p}<0.05)$. 


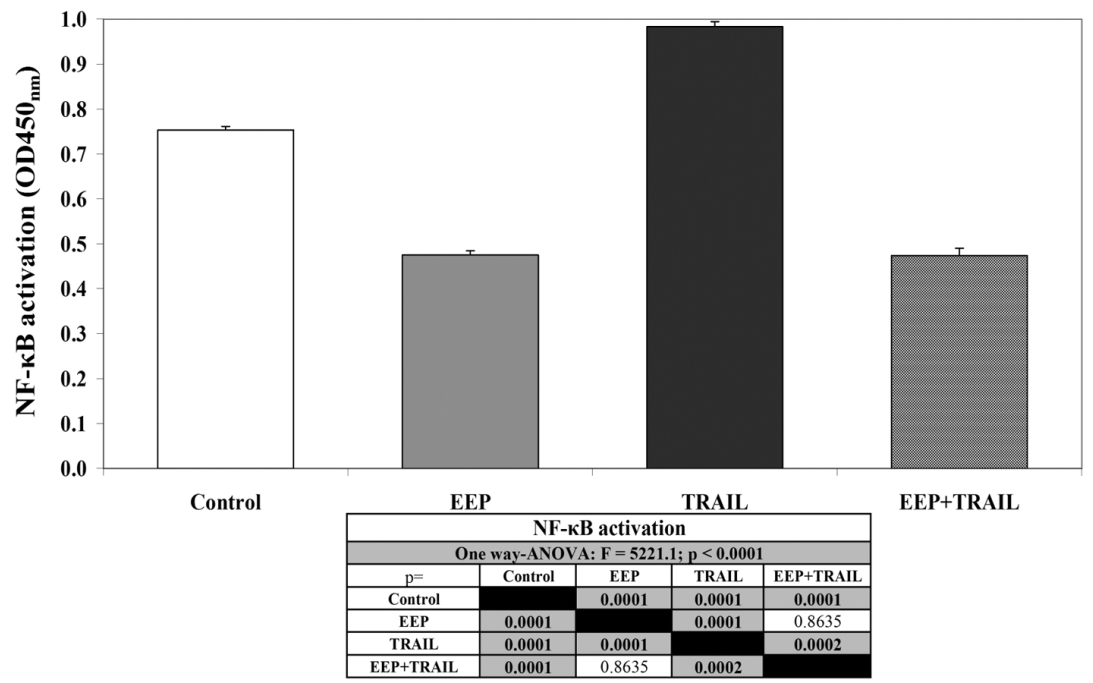

Figure 4. Effect of Brazilian green propolis and TRAIL on NF- $\mathrm{KB}$ activity in LNCaP prostate cancer cells. The cancer cells were incubated for $48 \mathrm{~h}$ with Brazilian EEP at a concentration of $50 \mu \mathrm{g} / \mathrm{ml}$ and/or TRAIL at a concentration of $100 \mathrm{ng} / \mathrm{ml}$. The values represent the means \pm SD of three independent experiments performed in duplicate $\mathrm{n}=6(\mathrm{p}<0.05)$. The effect of Brazilian EEP and/or TRAIL on the NF- $\mathrm{kB}(\mathrm{p} 65)$ binding activity in nuclear extracts from LNCaP cells was measured using the ELISA-based TransAm NF-кB assay.

A

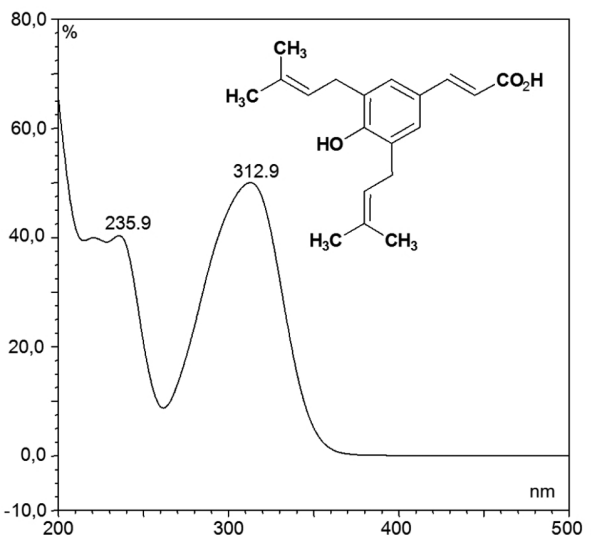

C

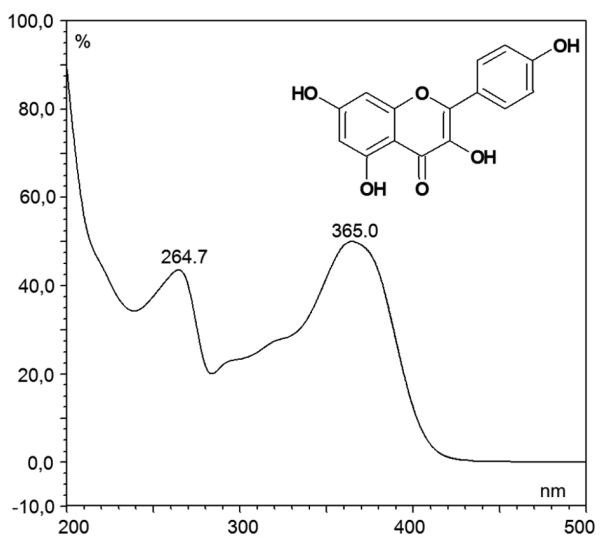

B

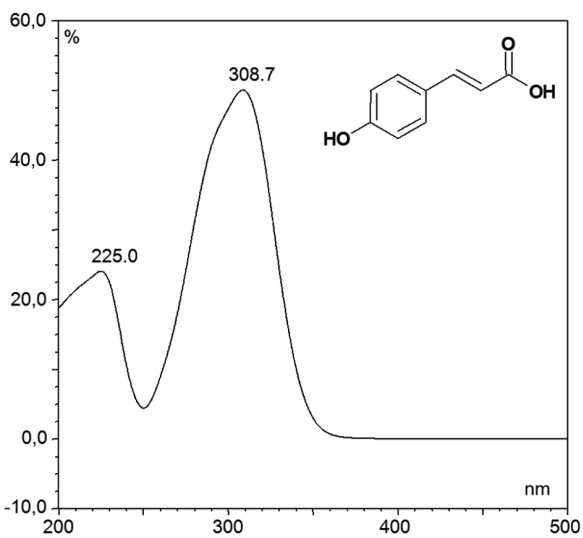

D

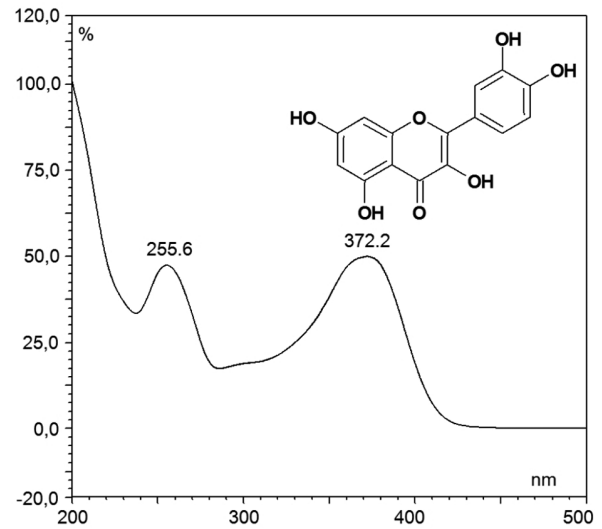

Figure 5. Chemical structures and UV spectra of the studied phenolic compounds identified in Brazilian green propolis. Each UV spectrum was recorded at the maximum of the peak corresponding to each investigated compound on the HPLC chromatogram of the standards mixture (see Fig. 6). (A) Artepillin C (3,5-diprenyl-4-hydroxycinnamic acid), (B) coumaric acid, (C) kaempferol and (D) quercetin.

activity in the nuclear extract with the ELISA-based TransAm $N F-\kappa B$ kit. Brazilian EEP decreased the expression of $N F-\kappa B$, in contrast to TRAIL, which induced the activation of NF- $\kappa \mathrm{B}$ in LNCaP cells, compared to the control. The co-treatment of EEP with TRAIL also significantly decreased NF- $\mathrm{B}$ expression through the inhibition of TRAIL-mediated NF- $\kappa \mathrm{B}$ 
A

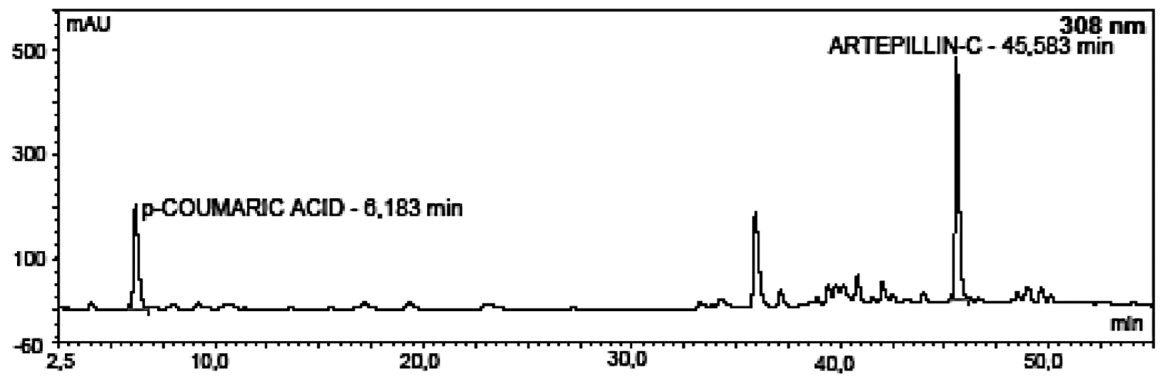

B

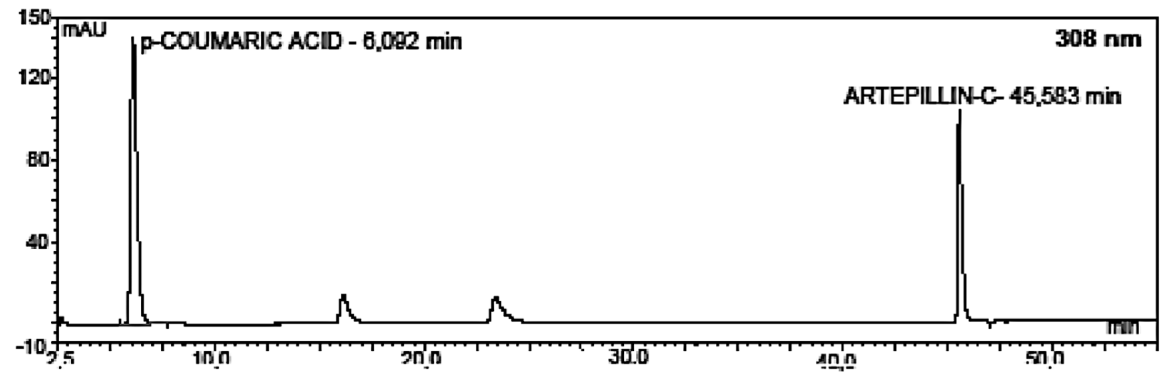

C

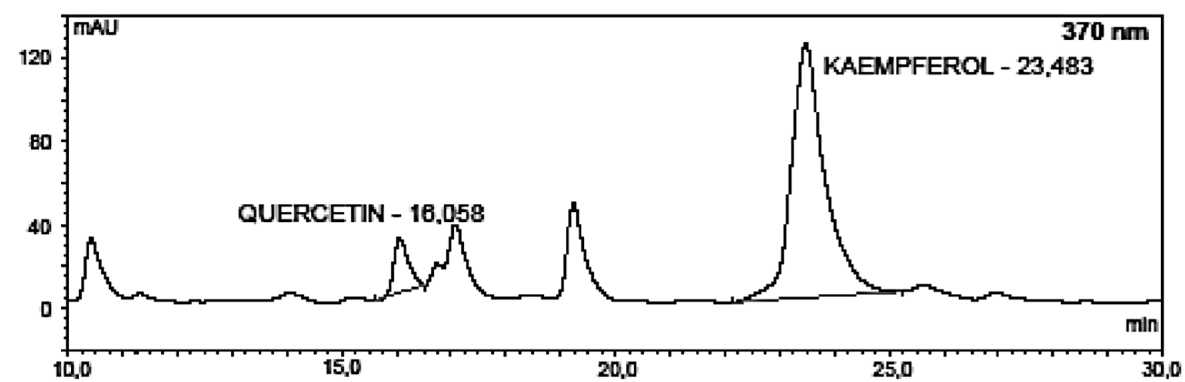

D

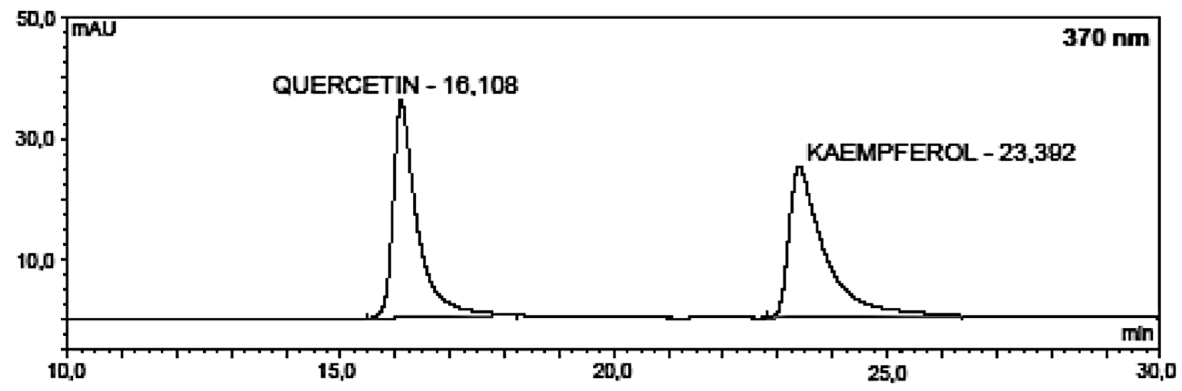

Figure 6. HPLC chromatograms of Brazilian green propolis extract and standards mixture of the studied phenolic compounds. Chromatograms (retention time range, $2.5-55 \mathrm{~min}$ ) recorded at $\lambda=308 \mathrm{~nm}$ for the determination of $p$-coumaric acid and artepillin C: (A) Chromatogram of Brazilian EEP (concentration, $2.175 \mathrm{mg} / \mathrm{ml}$ of ethanol; injection volume, $10 \mu \mathrm{l}$ ), (B) chromatogram of the standards mixture (concentration of each compound, $20 \mathrm{mg} / \mathrm{ml}$ of ethanol; injection volume, $15 \mu \mathrm{l}$ ). Chromatograms (retention time range, $10-30 \mathrm{~min}$ ) recorded at $\lambda=370 \mathrm{~nm}$ for the determination of quercetin and kaempferol: (C) Chromatogram of the Brazilian EEP (concentration, $43.5 \mathrm{mg} / \mathrm{ml}$ of ethanol; injection volume, $10 \mu \mathrm{l}$ ), (D) chromatogram of the standards mixture (concentration of each compound, $20 \mathrm{mg} / \mathrm{ml}$ of ethanol; injection volume, $15 \mu \mathrm{l})$.

activation by Brazilian green propolis in prostate cancer cells.

HPLC-DAD analyses of Brazilian green propolis and detection of phenolic components from the EEP sample. The anti-cancer and chemopreventive activities of EEP are due to its phenolic components, which are capable of inducing apoptosis in cancer cells. Fig. 5A-D presents the structures of the main phenolic components identified in Brazilian green propolis as determined by HPLC-DAD. Quantitative determinations were performed at selected wavelengths at which these compounds displayed a maximum absorption on their UV spectrum. In Fig. 6, HPLC chromatograms recorded at 308 and $370 \mathrm{~nm}$ are shown for the propolis extract and the studied bioactive phenolic compound standards mixture. The concentrations of the determined compounds, expressed as the mean of five analyses $(\mathrm{n}=5)$ in $\mathrm{mg} / 100 \mathrm{~g}$ of propolis extract, are as follows: $p$-Coumaric acid, $1502.66 \pm 45.59$; 


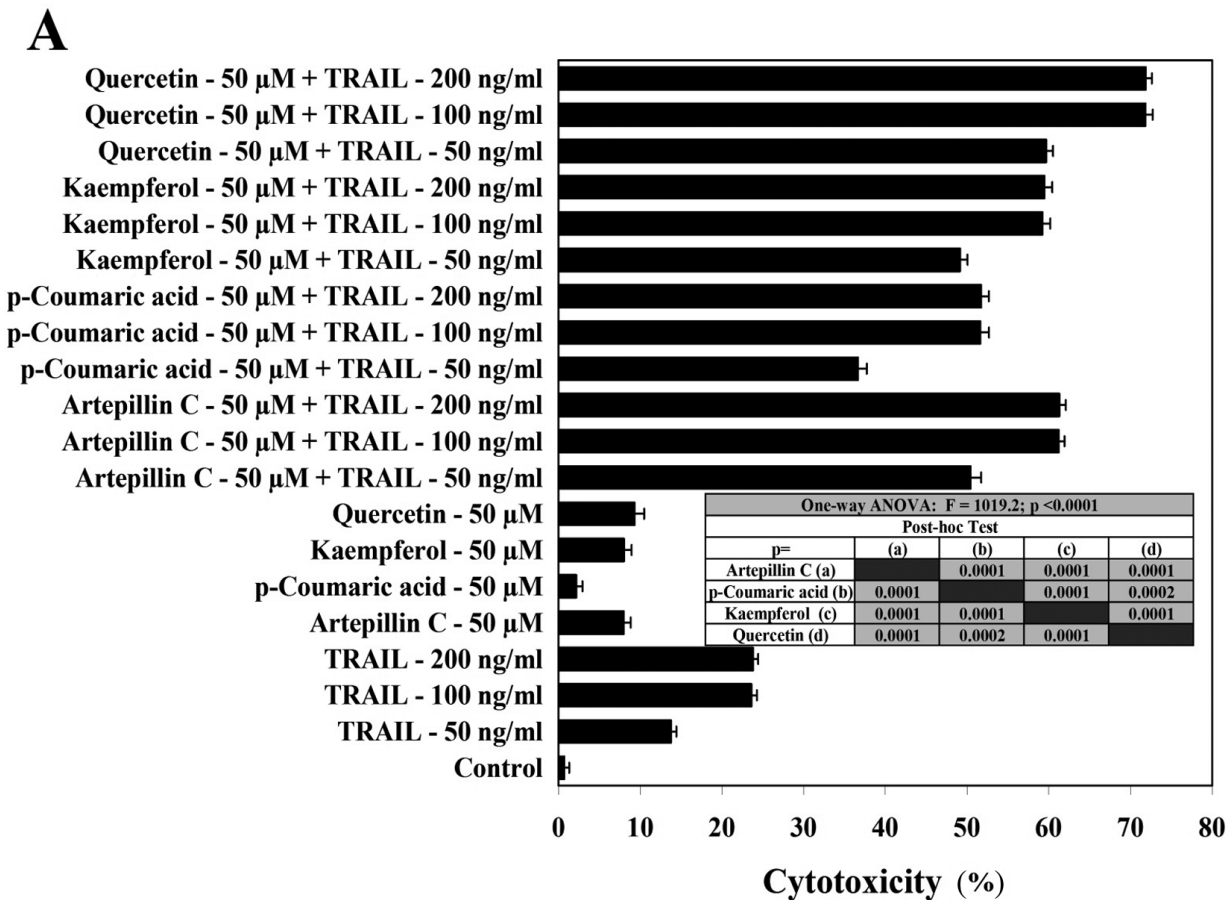

B

Cytotoxicity (\%)

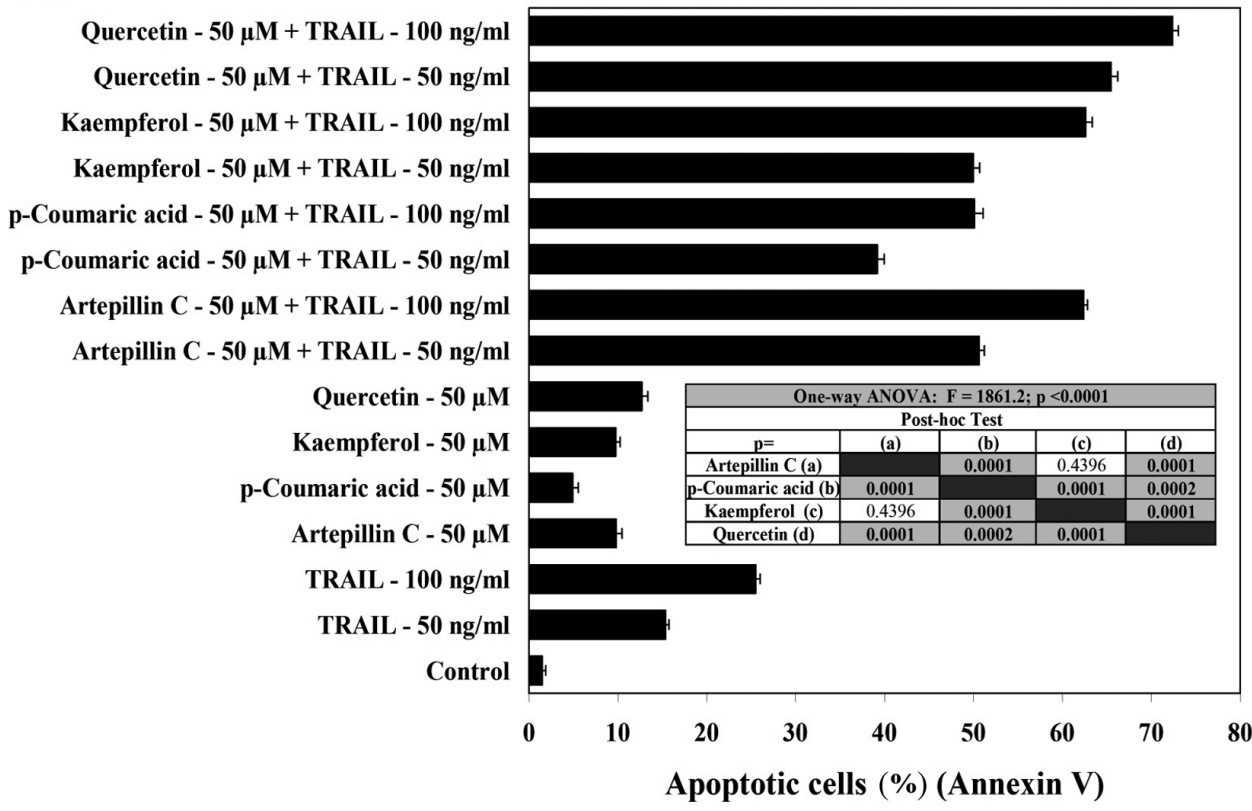

Figure 7. Cytotoxic and apoptotic effects of TRAIL in combination with phenolic components detected in Brazilian green propolis on LNCaP prostate cancer cells. (A) Cytotoxic activity of TRAIL in combination with Brazilian EEP phenolic compounds in LNCaP cells. The cancer cells were incubated for $48 \mathrm{~h}$ with TRAIL at concentrations of 50-200 $\mathrm{ng} / \mathrm{ml}$ and Brazilian EEP phenolic compounds at a concentration of $50 \mu \mathrm{M}$. The values represent the means \pm SD of three independent experiments performed in quadruplicate $n=12(\mathrm{p}<0.05)$. The percentage of cell death was measured by MTT cytotoxicity assay. (B) TRAILinduced apoptosis in combination with Brazilian EEP phenolic compounds in LNCaP prostate cancer cells. The cancer cells were incubated for $48 \mathrm{~h}$ with TRAIL at concentrations of 50-100 ng/ml and Brazilian EEP phenolic compounds at a concentration of $50 \mu \mathrm{M}$. The values represent the means \pm SD of three independent experiments performed in duplicate $n=6(p<0.05)$. Apoptotic cell death was detected by annexin V-FITC staining using flow cytometry.

artepillin C, 5886.53 \pm 257.65 ; quercetin, 48.44 \pm 1.62 ; and kaempferol, 319.98 \pm 9.54 .

Cytotoxic and apoptotic effects of phenolic components detected in Brazilian green propolis on prostate cancer cells. We examined the cytotoxic and apoptotic effects of the four main components detected in the Brazilian green propolis sample: Artepillin C, quercetin, kaempferol and $p$-coumaric acid on LNCaP cells. After a 48-h exposure of the cancer cells to phenolics, the cytotoxicity was measured by MTT assay and apoptosis (annexin V staining) was determined by flow cytometry. The compounds at concentrations of 20-50 $\mu \mathrm{M}$ induced $1.47 \pm 0.57$ to $9.33 \pm 1.16 \%$ cytotoxicity in prostate cancer cells (Fig. 7A). The apoptotic activity of the studied EEP constituents at a concentration of $50 \mu \mathrm{M}$ was between $4.93 \pm 0.63$ and $12.69 \pm 0.68 \%$ (Fig. 7B). Quercetin possessed the most potent anti-cancer properties, in contrast to $p$-coumaric acid, which exhibited the lowest efficacy to increase cell death. 
Cytotoxic and apoptotic effects of TRAIL in combination with phenolic components detected in Brazilian green propolis on prostate cancer cells. We investigated the cytotoxic and apoptotic effects of TRAIL in combination with the main constituents identified in Brazilian green propolis on $\mathrm{LNCaP}$ cells. The cytotoxicity after co-treatment of LNCaP cells with TRAIL at concentrations of $50-200 \mathrm{ng} / \mathrm{ml}$ and phenolic compounds at a concentration of $50 \mu \mathrm{M}$ was between $36.68 \pm 1.05$ and $71.88 \pm 0.75 \%$. Fig. 7A demonstrates the cytotoxic activity measured by the MTT assay. TRAIL and the components detected in Brazilian EEP induced a cytotoxic effect on cancer cells through the engagement of apoptosis. The necrotic cell death percentage of LNCaP cells examined by Apoptest-FITC and the lactate LDH assay was near zero. Artepillin C, quercetin, kaempferol and $p$-coumaric acid strongly cooperated with TRAIL to induce apoptosis in prostate cancer cells. The percentage of apoptotic cells after a 48-h exposure to $50-100 \mathrm{ng} / \mathrm{ml}$ TRAIL with $50 \mu \mathrm{M}$ of phenolics was elevated to $50.62 \pm 0.61-62.38 \pm 0.43 \%$ for artepillin $\mathrm{C}$, to $65.49 \pm 0.72-72.38 \pm 0.66 \%$ for quercetin, to $49.98 \pm 0.71$ $62.61 \pm 0.76 \%$ for kaempferol and to $39.18 \pm 0.78-50.10 \pm 0.97 \%$ for $p$-coumaric acid. The annexin V-FITC staining determined by flow cytometry showed that the bioactive compounds found in Brazilian propolis enhanced the apoptotic activity of TRAIL against LNCaP cancer cells (Fig. 7B).

\section{Discussion}

Dysregulated apoptotic pathways are significant in the initiation and progression of prostate cancer $(4,7,17,39)$. The data accumulated from in vitro and in vivo studies suggest that TRAIL plays an important role in the maintenance of immune homeostasis, host tumour surveillance and defence against cancer cells (15-18). However, some tumour cells are resistant to TRAIL-mediated cytotoxicity (19). Previously we and others have demonstrated that the LNCaP cell line is resistant to TRAIL-induced apoptosis $(7,10,11,13,14,16$, $31,35,40)$. The recombinant human TRAIL used in this study is a soluble protein based on a natural ligand $(13,34)$. TRAIL resistance in cancer cells could be overcome by an extract rich in bioactive polyphenols (11). We tested the cytotoxic and apoptotic effects of TRAIL in combination with Brazilian EEP on prostate cancer cells. Our results show that Brazilian green propolis markedly augments TRAIL-mediated apoptosis in $\mathrm{LNCaP}$ prostate cancer cells. We investigated the mechanism by which propolis modulates the TRAIL-induced death and sensitizes TRAIL-resistant prostate cancer cells.

Apoptosis can be triggered by two major mechanisms: The intrinsic pathway, which is induced by the disruption of mitochondrial membrane integrity (mitochondrial dysfunction), and the extrinsic pathway, which is associated with the stimulation of DRs located on the cell membrane $(17,39)$. We studied the involvement of the $\Delta \Psi \mathrm{m}$ on the apoptotic process induced by TRAIL in combination with Brazilian green propolis. The co-treatment of TRAIL and Brazilian EEP significantly reduced the $\Delta \Psi \mathrm{m}$ in LNCaP cells compared to the treatment with TRAIL or EEP alone. The binding of TRAIL to the DRs, TRAIL-R1 (DR4) and/or TRAIL-R2 (DR5), on the surface of cancer cells initiated the extrinsic apoptotic pathway. Brazilian propolis enhanced the sensitivity of LNCaP prostate cancer cells to TRAIL by the regulation of TRAIL-R2 expression. Dietary flavonoids, including apigenin, baicalein and quercetin have been shown to increase the expression of the DR, TRAIL-R2, on the surface of prostate cancer cells and to augment TRAIL-mediated apoptosis $(6,9,12)$. In some cell lines, DR engagement of the extrinsic pathway is sufficient to induce apoptosis. However, in most cell line types, apoptosis requires the amplification of the extrinsic pathway through the intrinsic signalling pathway (19). Our findings show that Brazilian green propolis sensitizes TRAIL-resistant LNCaP cells to TRAIL-induced apoptosis via the modulation of the intrinsic and extrinsic apoptotic pathways. A similar observation was described by Siddiqui et al and Shankar et al in their in vitro studies with epigallocatechin-3-gallate (EGCG), resveratrol and curcumin. Resveratrol, a main compound found in red wine, curcumin (the active component of the spice turmeric derived from the rhizome of Curcuma longa) and EGCG (a green tea polyphenol), all helped LNCaP cells overcome TRAIL resistance through the upregulation of the DRs, TRAIL-R1 and/or TRAIL-R2, and caused a decrease in the $\Delta \Psi \mathrm{m}$ in prostate cancer cells $(7,10,35)$. They reported that the sensitization of TRAIL-resistant LNCaP cells to TRAIL-induced apoptosis by bioactive agents is performed via the regulation of both the intrinsic and extrinsic apoptotic pathways.

The nuclear transcription factor $\mathrm{\kappa B}$ is involved in immune and inflammatory responses and in the control of cell proliferation, apoptosis and metastasis. NF- $\mathrm{kB}$ acts as a survival factor by protecting tumour cells from TRAIL-induced apoptosis. LNCaP prostate cancer cells express constitutively active NF- $\mathrm{KB}$, which has been suggested to mediate the resistance of LNCaP cells to TRAIL by inhibiting caspases and Bid activation (17,36,38,41-43). Guseva et al described the role of TRAIL-mediated NF- $\mathrm{KB}$ activation in LNCaP cancer cells in the mechanism of resistance to TRAIL (44). In this study, we report that the inhibition of NF- $\mathrm{KB}$ activation in LNCaP cells after TRAIL treatment by Brazilian EEP augments the apoptotic effect. Our findings confirm that the downregulation of NF- $\mathrm{kB}$ sensitizes prostate cancer cells to TRAIL in vitro. Deeb et al and Shankar et al showed that curcumin also inhibits the activation of NF- $\mathrm{\kappa B}$ and sensitizes LNCaP prostate cancer cells to TRAIL-mediated apoptosis $(36,38,41-43)$.

Propolis contains various chemical components and exhibits a broad spectrum of biological activities $(20,23)$. The composition of propolis is complex and largely depends on the geographical origin and specific flora at the site of its collection $(11,29,45,46)$. Phenolic components contribute to the overall cancer preventive and anti-tumour properties of propolis $(11,28-30,47)$. Further in vitro studies have demonstrated that the flavone constituents of Mexican propolis induce apoptosis in pancreatic cancer and that propolines from Taiwanese propolis mediate apoptosis in melanoma $(29,48,49)$. The main components detected by HPLC-DAD in Brazilian green propolis are artepillin $\mathrm{C}, p$-coumaric acid, kaempferol and quercetin. These compounds were also previously identified in the same sample (50). The highest concentration in our propolis sample was achieved by 3,5-diprenyl-4-hydroxycinnamic acid, known as artepillin C. This cinnamic acid derivative is the major component found 
specifically in Brazilian green propolis from southeast Brazil, collected in the states of Minas Gerais and Sao Paulo from the plant Baccharis dracunculifolia. Baccharis dracunculifolia, the main botanical source of resins for the green propolis, determines the origin and composition of Brazilian EEP rich in artepillin C (45-47,51). The concentrations of quercetin and kaempferol in the investigated Brazilian propolis sample were much lower than those of artepillin $\mathrm{C}$ and $p$-coumaric acid. However, these compounds (quercetin and kaempferol) exhibited stronger free radical-scavenging activity than the other components of the propolis extract $(26,27)$. To find out which compounds identified in Brazilian EEP might be responsible for the enhancement of the apoptosis-inducing potential of TRAIL, we tested the effect of artepillin C, quercetin, kempferol and $p$-coumaric acid in combination with TRAIL on LNCaP prostate cancer cells. All of these compounds increased the percentage of cell death in TRAILinduced cytotoxicity and apoptosis. The obtained results suggest that Brazilian propolis restores TRAIL sensitivity in LNCaP prostate cancer cells through its phenolic components. The strongest activity in combination with TRAIL against LNCaP cells was exhibited by quercetin. The less active compounds were artepillin $\mathrm{C}$ and kaempferol. In contrast, $p$-coumaric acid showed the smallest effect on TRAILinduced apoptosis. Similar studies have described the synergistic apoptotic effect of TRAIL with naturally occurring polyphenols on cancer cells. Quercetin enhanced the TRAILmediated cytotoxicity by increasing TRAIL-R 2 expression, activating caspases and decreasing the expression of the antiapoptotic serine/threonine kinase, Akt, or survivin in prostate cancer, lung cancer and hepatoma cells (12,52-55). Kaempferol sensitized colon cancer cells through the upregulation of TRAIL-R2 expression (56).

Chemoprevention is a means of tumour control in which malignancy is prevented or reversed by nutritional or pharmacological intervention with natural or synthetic substances $(57,58)$. Natural products have been utilized in cancer prevention because of their ability to induce apoptosis $(59,60)$. The role of dietary products in the prevention of prostate cancer has been confirmed in numerous preclinical and epidemiological studies (57,61-63). Dietary agents derived from a natural source are considered pharmacologically safe and have potential use in cancer chemoprevention (3). The TRAIL-mediated apoptotic pathway could be a target of chemopreventive agents in prostate cancer cells (64). Brazilian propolis has been shown to inhibit prostate cancer cell proliferation and to mediate programmed cell death (65). In addition to the direct antitumour activity, propolis has been shown to support anti-cancer immune defence $(28,30)$. We have previously shown that European or Brazilian EEP and its main phenolic compounds enhance the apoptosis-inducing potential of TRAIL and sensitize TRAIL-resistant LNCaP prostate cancer cells (11). In this study, we examined for the first time the mechanisms by which propolis sensitizes cancer cells to TRAIL. EEP affects the intrinsic and extrinsic apoptotic pathway and regulates NF- $\kappa \mathrm{B}$ activity. The ability of Brazilian green propolis to augment TRAIL-mediated apoptosis could be one of the mechanisms responsible for its cancer preventive effects.

In conclusion, our study demonstrates that Brazilian EEP helps prostate cancer cells overcome TRAIL resistance. The strong cytotoxic and apoptotic effects of green propolis in combination with TRAIL on prostate cancer cells suggest their potential use in chemoprevention strategies. The enhanced apoptotic effect of TRAIL by Brazilian EEP was mediated by both receptor TRAIL-R2-dependent and mitochondrial pathways.

\section{Acknowledgements}

This sudy was supported by a research grant (no. KNW-1087/10) from the Medical University of Silesia in Katowice, Poland. We thank Mr. Rindai Yamamoto, the President of Nihon Natural Foods Co., Ltd. (Tokyo, Japan), and Mrs. Etsuko Yamamoto, the President of Komyodo Kampo Shoyaku Co., Ltd. (Tokyo, Japan) for the sample of Brazilian green propolis.

\section{References}

1. Heidenreich A, Aus G, Bolla M, Joniau S, Matveev VB, Schmid HP, Zattoni F; European Association of Urology: EAU guidelines on prostate cancer. Eur Urol 53: 68-80, 2008.

2. Crawford ED: Understanding the epidemiology, natural history, and key pathways involved in prostate cancer. Urology 73: 4-10, 2009.

3. Syed DN, Suh Y, Afag F and Mukhtar H: Dietary agents for chemoprevention of prostate cancer. Cancer Lett 265: 167-176, 2008.

4. Khan N, Adhami VM and Mukhtar H: Apoptosis by dietary agents for prevention and treatment of prostate cancer. Endocr Relat Cancer 17: 39-52, 2009.

5. Sonn G, Aronson W and Litwin MS: Impact of diet on prostate cancer: review. Prostate Cancer Prostatic Dis 8: 304-310, 2005.

6. Horinaka M, Yoshida T, Shiraishi T, Nakata S, Wakada M and Sakai T: The dietary flavonoid apigenin sensitizes malignant tumor cells to tumor necrosis factor-related apoptosis-inducing ligand. Mol Cancer Ther 5: 945-951, 2006.

7. Shankar S, Chen Q, Siddiqui I, Sarva K and Srivastava RK: Sensitization of TRAIL-resistant LNCaP cells by resveratrol (3,4',5-trihydroxystilbene): molecular mechanisms and therapeutic potential. J Mol Signal 2: 27-36, 2007.

8. Shankar S, Siddiqui I and Srivastava RK: Molecular mechanisms of resveratrol (3,4',5-trihydroxy-trans-stilbene) and its interaction with TNF-related apoptosis inducing ligand (TRAIL) in androgen-insensitive prostate cancer cells. Mol Cell Biochem 304: 273-285, 2007.

9. Tanaguchi H, Yoshida T, Horinaka M, Yasuda T, Goda AE, Konishi M, Wakada M, Kataoka K, Yoshikawa T and Sakai T: Baicalein overcomes tumor necrosis factor-related apoptosisinducing ligand resistance via two different cell specific pathways in cancer cells but not in normal cells. Cancer Res 68: 8918-8927, 2008.

10. Siddqui IA, Malik A, Adhami VM, Asim M, Hafeez BB, Sarfaraz S and Mukhtar H: Green tea polyphenol EGCG sensitizes human prostate carcinoma LNCaP cells to TRAILmediated apoptosis and synergistically inhibits biomarkers associated with angiogenesis and metastasis. Oncogene 27: 2055-2063, 2008.

11. Szliszka E, Czuba ZP, Bronikowska J, Mertas A, Paradysz A and Krol W: Ethanolic extract of propolis (EEP) augments TRAILinduced apoptotic death in prostate cancer cells. Evid Based Complement Alternat Med doi: 10.1093/ecam/nep180, 2009.

12. Jung YH, Heo J, Lee YJ, Kwon TK and Kim YH: Quercetin enhances TRAIL-mediated apoptosis in prostate cancer cells via increased protein stability of death receptor 5. Life Sci 86: 351-357, 2010.

13. Szliszka E, Czuba ZP, Mazur B, Sedek L, Paradysz A and Krol W: Chalcones enhance TRAIL-induced apoptosis in prostate cancer cells. Int J Mol Sci 11: 1-13, 2010.

14. Fulda S and Debatin KM: Sensitization for tumor necrosis factor-related apoptosis-inducing ligand induced apoptosis by the chemopreventive agent resveratrol. Cancer Res 64: 337-346, 2004. 
15. Almasan A and Ashkenazi A: Apo2L/TRAIL: apoptosis signaling, biology and potential for cancer therapy. Cytokine Growth Factor Rev 14: 337-348, 2003.

16. Lee JY, Huerta-Yepez S, Vega M, Baritaki S, Spandidos DA and Bonavida B: The NO TRAIL to YES TRAIL in cancer therapy (Review). Int J Oncol 31: 685-691, 2007.

17. Bucur O, Ray S, Bucur MC and Almasan A: Apo2 ligand/tumor necrosis factor-related apoptosis-inducing ligand in prostate cancer therapy. Front Biosci 11: 1549-1568, 2006.

18. Thorburn A, Behbakht K and Ford H: TRAIL receptor-targeted therapeutics: resistance mechanisms and strategies to avoid them. Drug Resist Updat 11: 17-24, 2008.

19. Zhang L and Fang B: Mechanisms of resistance to TRAILinduced apoptosis in cancer. Cancer Gene Ther 12: 228-237, 2005.

20. Krol W, Scheller S, Czuba Z, Matsuno T, Zydowicz G, Shani J and Mos M: Inhibition of neutrophils' chemiluminescence by ethanol extract of propolis (EEP) and its phenolic components. J Ethnopharmacol 55: 19-25, 1996.

21. Yasui Y, Miyamoto S, Kim M, Kohno H, Sugie S and Tanaka T: Aqueous and ethanolic extract fractions from Brazilian propolis suppress azoxymethane-induced aberrant crypt foci in rat. Oncol Rep 20: 493-499, 2008.

22. Ishihara M, Naoi K, Hashita M, Itoh Y and Suzui M: Growth inhibitory activity of ethanol extracts of Chinese and Brazilian propolis in four human colon carcinoma cell lines. Oncol Rep 22: 349-354, 2009.

23. Viuda-Martos M, Ruiz-Navajas Y, Fernandez-Lopez J and Perez-Alvarez JA: Functional properties of honey, propolis, and royal jelly. J Food Sci 73: 117-124, 2008.

24. Krol W, Czuba Z, Scheller S, Gabrys J, Grabiec S and Shani J: Anti-oxidant property of ethanolic extract of propolis (EEP) as evaluated by inhibiting the chemiluminescence oxidation of luminol. Biochem Int 21: 593-597, 1990.

25. Blonska M, Bronikowska J, Pietsz G, Czuba ZP, Scheller S and Krol K: Effects of ethanol extract of propolis (EEP) and its flavones on inducible gene expression in J774A.1 macrophages. J Ethnopharmacol 91: 25-30, 2004.

26. Kumazawa S, Hamasaka T and Nakayama T: Antioxidant activity of propolis of various geographic origins. Food Chem 84: 329-339, 2004

27. Ahn MR, Kumazawa S, Usui Y, Nakamura J, Matsuka M, Zhu F and Nakayama T: Antioxidant activity and constituents of propolis collected in various areas of China. Food Chem 101: 1383-1392, 2007.

28. Szliszka E, Czuba ZP, Domino M, Mazur B, Zydowicz G and Krol W: Ethanolic extract of propolis (EEP) enhances the apoptosis-inducing potential of TRAIL in cancer cells. Molecules 14: 738-754, 2009.

29. Li F, Awale S, Tezuka Y, Esumi H and Kadota S: Study of the constituents of Mexican propolis and their cytotoxic activity against PANC-1 human pancreatic cancer cells. J Nat Prod 73: 623-627, 2010.

30. Orsolic N, Saranovic AB and Basic I: Direct and indirect mechanisms of antitumour activity of propolis and its phenolic compounds. Planta Med 72: 20-27, 2006.

31. Szliszka E, Bronikowska J, Majcher A, Miszkiewicz J and Krol W: Enhanced sensitivity of hormone-refractory prostate cancer cells to tumor necrosis factor-related apoptosis-inducing ligand (TRAIL) mediated cytotoxicity by taxanes. CEJ Urol 62: 29-34, 2009.

32. Szliszka E, Czuba ZP, Jernas K and Krol W: Dietary flavonoids sensitize HeLa cells to tumor necrosis factor-related apoptosisinducing ligand (TRAIL). Int J Mol Sci 9: 56-64, 2008.

33. Bronikowska J, Szliszka E, Czuba ZP, Zwolinski D, Szmydki B and Krol W: The combination of TRAIL and isoflavones enhances apoptosis in cancer cells. Molecules 15: 2000-2015, 2010

34. Szliszka E, Czuba ZP, Mazur B, Paradysz A and Krol W: Chalcones and dihydrochalcones augment TRAIL-mediated apoptosis in prostate cancer cells. Molecules 15: 5336-5353, 2010.

35. Shankar S, Chen Q, Sarva K, Siddiqui I and Srivastava RK: Curcumin enhances the apoptosis-inducing potential of TRAIL in prostate cancer: molecular mechanisms of apoptosis, migration and angiogenesis. J Mol Signal 2: 1-14, 2007.

36. Shankar S, Ganapathy S, Chen Q and Srivastava RK: Curcumin sensitizes TRAIL-resistant xenografts: molecular mechanisms of apoptosis, migration and angiogenesis. Mol Cancer 7: 1-13, 2008.
37. Szliszka E, Mazur B, Zydowicz G, Czuba ZP, and Krol W: TRAIL-induced apoptosis and expression of death receptor TRAIL-R1 and TRAIL-R2 in bladder cancer cells. Folia Histochem Cytobiol 47: 579-585, 2009.

38. Deeb D, Jiang H, Gao X, Hafner MS, Wong H, Divine G, Chapman RA, Dulchavsky SA and Gautam SC: Curcumin sensitizes prostate cancer cells to tumor necrosis factor-related apoptosis-inducing ligand/Apo2L by inhibiting nuclear factorkappaB through supression of IkappaBalpha phosphorylation. Mol Cancer Ther 3: 803-812, 2004.

39. Fulda S and Debatin KM: Resveratrol-mediated sensitization to TRAIL-induced apoptosis depends on death receptor and mitochondrial signalling. Eur J Cancer 41: 786-798, 2005.

40. Van Ophoven A, NG CP, Patel B, Bonavida B and Belldegrun A Tumor necrosis factor-related apoptosis-inducing ligand (TRAIL) for treatment of prostate cancer: first results and review of literature. Prostate Cancer Prostatic Dis 2: 227-233, 1999.

41. Deeb D, Jiang H, Gao X, Divine G, Chapman RA, Dulchavsky SA and Gautam SC: Chemosensitization of hormone-refractory prostate cancer cells by curcumin to TRAIL-induced apoptosis J Exp Ther Oncol 5: 81-91, 2005.

42. Deeb D, Jiang H, Gao X, Al-Holou S, Danyluk AL, Dulchavsky SA and Gautam SC: Curcumin[1,7bis(4-hydroxy-3-methoxyphenyl)16-heptadine-3,5dione $\mathrm{C}_{21} \mathrm{H}_{20} \mathrm{O}_{6}$ ] sensitizes human prostate cancer cells to tumor necrosis factor-related apoptosis-inducing ligand/Apo2L-induced apoptosis by suppressing nuclear factorkappaB via inhibition of prosurvival Akt signaling pathway. J Pharmacol Exp Ther 321: 616-625, 2007.

43. Andrzejewski T, Deeb D, Gao X, Danyluk AL, Arbab AS, Dulchavsky SA and Gautam SC: Therapeutic efficacy of curcumin/TRAIL combination regiment for hormone-refractory prostate cancer. Oncol Res 17: 257-267, 2008.

44. Guseva NV, Taghiyev AF, Sturm MT, Rokhlin OW and Cohen MB: Tumor necrosis factor-related apoptosis-inducing ligandmediated activation of mitochondria-associated nuclear factor-kappaB in prostatic carcinoma cell lines. Mol Cancer Res 2: 574-584, 2004.

45. Salatino A, Teixeira EW, Negri G and Message D: Origin and chemical variation of Brazilian propolis. Evid Based Complement Alternat Med 2: 33-38, 2005

46. Teixeira EW, Negri G, Meira RM, Message D and Salatino A Plant origin of green propolis: bee behavior, plant anatomy and chemistry. Evid Based Complement Alternat Med 2: 85-92, 2005.

47. Paulino N, Abreu SR, Machado G and Silveira E: Scientific evidence to pharmacological anticancer action of Baccharis dracunculifolia Brazilian propolis. Rev Pesq Inov Farm 1: 15-26, 2009.

48. Chen CN, Wu CL and Lin JK: Propolin C induces apoptosis through activating caspases, Bid and cytochrome $\mathrm{c}$ release in human melanoma cells. Biochem Pharmacol 67: 53-66, 2004

49. Chen CN, Wu CL and Lin JK: Apoptosis of human melanoma cells induced by the novel compounds propolin A and propolin B from Taiwenese propolis. Cancer Lett 245: 218-231, 2007.

50. Ishiai S, Tahara W, Sasaki N, Hideki F, Hideo S, Dono Y, Nomura Y, Yamamoto E, Bomura S and Yamamoto R: Cancer cell proliferation control action of Brazilian propolis delivered from Baccharis dracunculifolia plant. Int Seminar Propolis 2: 34-37, 2008.

51. Bufalo MC, Candeias JM, Sousa JP, Bastos JK and Sforcin JM In vitro cytotoxic activity of Baccharis dracunculifolia and propolis agaist HEp-2 cells. Nat Prod Res 22: 1-9, 2010.

52. Kim YH and Lee YJ: TRAIL apoptosis is enhanced by quercetin through AKT dephosphorylation. J Cell Biochem 100: 998-1009, 2007.

53. Chen W, Wang X, Zhuang J. Zhang L and Lin Y: Induction of death receptor 5 and suppression of surviving contribute to sensitization of TRAIL-induced cytotoxicity by quercetin in non-small lung cancer cells. Carcinogenesis 28: 2114-2121, 2007.

54. Kim YH, Lee DH, Jeong JH, Guo ZS and Lee YJ: Quercetin augments TRAIL-induced apoptotic death: involvement of the ERK signal transduction pathway. Biochem Pharmacol 75: 1946-1958, 2008

55. Kim JY, Kim EH, Park SS, Lim JH, Kwon TK and Choi KS Quercetin sensitizes human hepatoma cells to TRAIL-induced apoptosis via Sp1-mediated DR5 upregulation and proteasomemediated c-FLIPS downregulation. J Cell Biochem 105: 1386-1398, 2008. 
56. Yoshida T, Konishi M, Horinaka M, Yasuda T, Goda AE, Taniguchi H, Yano K, Wakada M and Sakai T: Kaempferol sensitizes colon cancer cells to TRAIL-induced apoptosis. Biochem Biophys Res Commun 375: 129-133, 2008.

57. Syed DN, Khan N, Afag F and Mukhtar H: Chemoprevention of prostate cancer through dietary agents: progress and promise. Cancer Epidemiol Biomarkers Prev 16: 2193-2203, 2007.

58. Androutsopoulos VP, Papakyriakou A, Vourloumis D, Tsatsakis AM and Spandidos DA: Dietary flavonoids in cancer therapy and prevention: substrates and inhibitors oh cytochrome P450 CYP1 enzymes. Pharmacol Therap 126: 9-10, 2010.

59. Patel D, Shukla S and Gupta S: Apigenin and cancer chemoprevention: Progress, potential and promise (Review). Int J Oncol 30: 233-245, 2007.

60. Zhou W, Kallifatidis G, Baumann B, Rausch V, Mattern J, Gladkich J, Giese N, Moldenhauer G, Wirth T, Büchler MW, Salnikov AV and Herr I: Dietary polyphenols quercetin targets pancreatic cancer stem cells. Int J Oncol 37: 551-561, 2010.
61. Pathak SK, Sharma RA and Mellon JK. Chemoprevention of prostate cancer by diet-derived antioxidant agents and hormonal manipulation (Review). Int J Oncol 22: 5-13, 2003.

62. Hsieh TC and Wu JM: Ethanolic extracts of herbal supplement Equiguard $^{\mathrm{TM}}$ suppress growth and control gene expression in CWR22Rv1 cells representing the transition of prostate cancer form androgen dependence to refractory status. Int J Oncol 32: 209-219, 2008

63. Wang LG and Chiao JW. Prostate cancer chemoprevention activity of phenethyl isothiocyanate through epigenetic regulation. Int J Oncol 37: 533-539, 2010.

64. Szliszka E and Krol W: The role of dietary polyphenols in TRAIL-induced apoptosis for cancer chemoprevention. Eur J Cancer Prev 20: 63-69, 2011.

65. Li H, Kapur A, Yang JX, Srivastava S, McLeod DG, ParedesGuzman JF, Daugsch A, Park YK and Rhim JS: Antiproliferation of human prostate cancer cells by ethanolic extracts of Brazilian propolis and its botanical origin. Int J Oncol 31: 601-606, 2007. 